\title{
PEMIKIRAN POLITIK TAN MALAKA TENTANG KONSEP NEGARA INDONESIA
}

\author{
Oleh: \\ Ponirin \\ Agum Patria Silaban
}

\begin{abstract}
It aims to test anything that influences the Political thinking Tan Malaka about the Consept of the Indonesian State, setting aside the concept of the state in the view of Tan Malaka and putting forth the effort the makes in fulfilling the concept of a joyful state. This type of research is a study literature. As for data collection techniques in this study is a library study, it means the author did reseach by collecting books, documents, articles, scripts, and the like. With the approach: textual studies, context studies, and historical studies. The data analysis of the data is heuristic, criticism, interpretation, and presentation. From the results of the research, it is known that Tan Malaka was a hero of the independence movement, he was born in the village of Pandan Gadang, not far from the Suliki Sprout, Limopilih Koto Regency, East Sumatera. He began to think of the fate of this people who were colonized after education in the Netherlands. The influence of circumstances and understanding is like the circumstances of his people, then education that this finally influenced by Marxism and the revolutiomary movement of Europe (the French, British, and Russian Revolutions) have set the mind to a left (Communist). Long before the other leading figures of independence, Tan Malaka had designed the consep of the Indonesian state before the independent of Indonesia. He saw and compared the concept of repulic and kingdom. For him the kingdom is irrelevant to the welfare of the people. Tan Malaka would prefer the concept of a union or a republic with a democratic system. For him the people must be in charge.then it may be concluded tha the concept of the Indonesian state tha Tan Malakan was the Democratic
\end{abstract}

Key word : Thinking, Tan Malaka, Indonesian State 


\section{I.PENDAHULUAN}

Kemerdekaan yang berujung pada lahirnya sebuah negara adalah buah perjuangan ribuan nama, hasil pemikiran yang benar-benar matang. Namun banyak sosok yang tidak tercatat dalam sejarah bangsa. Nama-nama yang diabaikan dan dilupakan, disingkirkan karena konflik ideologi dan kepentingan. Salah satunya adalah Tan Malaka, pahlawan nasional yang absen dalam pelajaran sejarah kita. Memperjuangkan kemerdekaan dengan segala daya, buah pemikiran, diasingkan dan terbunuh di medan grilya. Sudah lama Tan Malaka berkalang tanah, adakah warisannya yang punah?

Tan Malaka memiliki peranan politik terhadap perjuangan negara Indonesia. Tan Malaka di hadapan polisi Inggris Murphy di Hongkong, 1932 seperti ditulisnya dalam buku Dari Penjara ke Penjara: Ingatlah bahwa dari alam kubur suara saya akan lebih keras daripada diatas bumi. Pernyataan itu seakan nyata. Tumbangnya orde baru kita akan menjumpai banyak tulisan-tulisan Tan Malaka yang naik kepermukaan. Pemuda dan mahasiswa saat itu banyak yang tertarik dengan sosoknya, sehingga banyak usahausaha yang dilakukan untuk mencari tau siapa sebenarnya Tan Malaka. Banyak bukubukunya yang kontroversial hingga dianggap terlarang. Salah satu dari tulisan fenomenalnya adalah Madilog (Materialisme, Dialektika dan Logika), Aksi Massa, Naar De Republik (Menuju Republik Indonesia), semangat muda, merdeka 100 persen dan lain sebagainya mulai tersebar dimana-mana.

Jauh hari Tan Malaka telah memikirkan tentang konsep sebuah negara menurut Idealnya. Sebut saja dalam Tulisannya Naar De Republik Indonesia (Menuju Republik Indonesia). Tan Malaka adalah pengagas pertama Republik Indonesia. Gigih menentang kolonialisme, sebagian besar hidupnya berada didalam pengusiran dan pembuangan. Oleh karena pemikirannya Tan Malaka sering disebut sebagai bapak Republik. Gagasan-gagsannya menjadi pegangan dan pemikirannya banyak diikuti oleh tokoh-tokoh pergerakan. Saat ini bentuk negara Indonesia adalah Republik, adakah ide Republik ini termotivasi dari pemikiran Tan Malaka? Sehingga founding father dan tokoh-tokoh perjuangan lainnya memilih bentuk negara Indonesia kedalam 
Republik. Dari Tan Malaka Soekarno banyak belajar. Apakah benar Tan Malaka adalah guru politik Soekarno? Apakah benar konsep negara Indonesia terinspirasi dari Tan Malaka?

Tidak bisa kita pungkiri bahwa beliau merupakan salah satu orang yang berjuang dengan jalan pikirannya sendiri untuk memerdekakan Indonesia. Berdasarkan penjelasan diatas penulis tertarik untuk membedah pola pemikiran politik Tan Malaka tentang konsep negara. Gagasan-gagasannya yang penuh kontroversi membuat takjub banyak kalangan muda/mahasiswa. Oleh karena itu, jika dibandingkan dengan tokohtokoh perjuangannya lainnya, pemikitan Tan Malaka itu unik dan menarik untuk dikaji. Yaitu pemikiran tentang negara, jauhari Tan Malaka sudah memikirkannya sebelum Indonesia merdeka.

Dalam penelitian ini, penulis menggunakan jenis penelitian berdasarkan tujuan yaitu penelitian dasar (Basic Research). Atau murni. Jujun Suriasumantri dalan Sugiyono (2015:9) menyatakan bahwa penelitian dasar (murni) adalah penelitian yang bertujuan menemukan pengetahuan baru yang sebelumnya belum pernah diketahui. Lebih jelas lagi Sugiyono (2015:15) menjelaskan penelitian murni pada umumnya menggunakan metode eksperimen dan kualitatif. Oleh karena itu, dalam hal ini penulis memilih menggunakan metode kualitatif sebagai metode penelitian.

\section{II.PEMBAHASAN}

\section{A. Faktor yang mempengaruhi pemikiran Tan Malaka}

Dalam buku Zulhasril Natsir berjudul Tan Malaka dan Gerakan Kiri Minangkabau mengkaji hubungan antara kerevolusioneran Tan Malaka dnega aspek sosial budaya Minangkabau dengan gerakan kiri yang anti penjajahan. Buku tersebut mencoba menguak unsur-unsur egaliter Minangkabau dengan gerakan kiri yang dilahirkan dari tokoh-tokoh Minangkabu. Formulasi ideologi Tan malaka merupakan wujud dari jejak kebudayaan dan sejarah yang ia lalui dengangagasan seperi Marxisme yang di peroleh selama perjuangan di Eropa, Asia dan Di Tanah Air. 
Kebiasaan anak laki-laki Minang elain diajari silat juga diwajibkan untuk mengaji setiap harinya. Sebagai anak yang lahir dari keluarga Islam yang taat tentu ia memahami kepercayaannya tersebut. bahkan dikatakan dalam buku Islam dalam Tinjauan Madilog (1951), sewaktu kecil Tan Malaka sudah memahami tafsir Al-Quran da dijadikan guru muda. Berangkat dari pemahamannya aka Islam, ditemukan kesamaan pergerakan sosialisme yang ia perjuangkan. Kuatnya pemahaman Islam yang ada dalam dirinya membuat dirinya di cap Trotskiis (Murtad dari Komunis).

Sejak lahir Tan Malaka sudah hidup dalam keadaan terjajah, ia lahir diperkirakan pada tahun 1894 dan pada tahun 1903 ia telah masuk ke sekolah rendah. Sementara pada tahun 1899, telah mengaung sebuah gagasan yang di lontarkan oleh Conrad Theodore Van Deventer lewat tulisan yang diterbitkan dalam media berkala $D e$ Gids berjudul Een Eereschuld (hutang kehormatan) pada tahun 1899 (Suhartono, 1994:16).

Bisa dikatakan bahwa Tan Malaka merupakan salah satu imbas dari politik etis yang sedang mengaung di Indonesia saat itu. Menempuh pendidikan di Belanda, lalu pada tahun 1919 Tan Malaka kembali pulang ke Indonesia dengan berbekal pengetahuan yang ia dapatkan selama menempuh pendidikan. Sekolah pertama yang ia duduki adalah sebagai guru sekolah untuk anak-anak perkebunan Sumatera Timur. Disanalah tempat para kapitalis bercokol mengeksploitasi tanah perkebunan dan sibuk menyiksa buruh-buruh pribumi.

Pelan namun pasti menurut penulis, Tan Malaka masuk dalam pergerakan politik yang bisa saja meletakkan diri dalam dua pilihan yaitu tunduk atau melawan. Yang antara bertahan sebagai guru dengan mendapat gaji tinggi dari keringat dan darah proletar negerinya atau mencampakkan semua kemewahan dan menuju perlawan praksis. Tan Malaka menyeberang ke pusat pergerakan yaitu tanah Jawa dengan dendam dan amarah yang menyala-nyala. Disana ia bertemu dengan tokoh-tokoh pergerakan dan bergabung dengan Serikat Dagang Islam (SDI) dan juga menjadi ketua PKI menggantikan Semaun. Organisasi inilah menjadi alat politik dan perlawanan awal Tan Malaka, hingga pada akhirnya ia juga membentuk Partai Republik Indonesia dan 
Partai Murba. Yang tidak bertahan dengan Lama. Saat memasuki zona tidak nyaman yang benar-benar ia sadari berbahaya, secara sadar dalam dirinya berani untuk memasuki gelanggang pergerakan rakyat yang nyata dan menentang secara langsung kolonialisme dan imperialisme.

\section{B. Pengaruh Marxisme}

PKI adalah partai Marxis terbesar dan terpenting di Indonesia. Sejarah partai ini dipenuhi oleh masalah-masalah yang muncul terutama dari dikotomi antara ideologi Marxis yang diwakili oleh komintern (Komunis Internasional) dengan realitas kehidupan Indonesia. Karena masalah ini berasal dari perbedaan latar belakang yang sangat esensial tidak hanya dari perkembangan PKI itu sendiri tetapi juga peran orisinil Marxis dalam arus besar nasionalisme Indonesia.

Berdasarkan penjelasan diatas, penulis ingin mengaitkan antara gaya berpikir Tan Malaka. Tidak bisa dipungkiri bahwa pemikiran revolusioner Tan Malaka banyak dipengaruhi oleh ideologi Marxisme. Bahwa ia juga terlibat dan bahkan menjadi ketua PKI, serta merta menjadi delegasi Komintern mewakili Asia di moskow. Hal ini sudah cukup membuktikan bahwa Tan Malaka merupakan seorang Marxis menurut hemat penulis.

Sementara teori revolusioner sendiri Tan Malaka mempelajarinya dari revolusi Perancis. Filsafat materialisme dialektika dan historis ala Karl Marx, mencoba dikembangkan oleh Tan Malaka dalam konteks yang berbeda. Yaitu dengan melihat situasi dan kondisi Indonesia yang sedang terjajah saat itu. Marxisme adalah sisten pemikiran daripada pandangan-pandangan Karl Marx. Menurut Lenin, Marxisme adalah seni yang meneruskan dan menyempurnakan ketiga aliran ideologi yang pokok pada abad ke -19 yang masing-masing diwakili oleh tiga negeri paling maju dari sejarah umat manusia yaitu, filsafat klasik Jerman, Ekonomi Politik Klasik Inggris dan Sosialisme Perancis yang dirangkai dengan ajaran revolusioner Perancis.

\section{Hakikat Negara Indonesia Menurut Tan Malaka}


Tan Malaka sepakat dengan Marx bahwa negara itu sebagai manifestasi dari pertentangan klas. Jika didalam masyarakat terdapat dua kelas yang bertentangan dan tidak mungkin lagi di damaikan maka akan muncul sebuah kekuasan yang akan membatasi dan menempatkan pertentangan didalam masyarakat tersebut. kekuasan muncul dari masyarakat namun kemudian akan semakin mengasikkan diri dari masyarakat. peran negara seolah-olah sebagai wasit dari semua pertikaian yang berdiri di atas semua kepentingan. Tan Malaka banyak menjelaskan didalam buku-bukunya tentang negara, hilang timbulnya negara dan tiimbul hilangnya negara. Dalam pemahaman Tan Malaka negara dapat ditumbangkan jika kondisi obyektif masyarakat sudah cukup. Kondisi obyektif tersebut terletak pada kondisi kebutuhan dan kemakmuran. Tan Malaka lebih banyak merujuk kepada negara kapitalis. Pengertian masa dari zaman ketangan para proletar untuk Indonesia Tan Malaka menyebutnya dengan Murba.

Dalam artian Negara Indonesia muncul dari hasil revolusi nasional mengusir penjajahan ekonomi dan politik bangsa asing yang bercokol di Indonesia saat itu. Untuk itu revolusi nasional diperlukan guna menciptakan sebuah tatanan hidup tanpa penindasan dan berpihak kepada keadilan, penataan kepemilikan alat produksi, strategi pembangunan nasional harus dipersiapkan agar imperialis tidak kembali walaupun hanya dalam bentuk penguasaan ekonomi.

\section{Pandangan Tan Malaka terhadap Trias Politika}

Sementara jika kita membaca bukunya Naar De Republik (1925), menerangkan dalam bukunya bahwa sejatinya ia memikirkan konsep republik namun tak menganut sistem parlemen (Trias Politika). negara yang menganut prinsip trias politika yang ada dalam sistem parlementer adalah kekonyolan dan hanya menguntungkan sebagian kecil rakyat. Terutama dalam konteks negara yang abrur merdeka, pemisahan antara lembaga kekuasaan akan menyebabkan kesenjangan dalam memahami realitas sehingga akan memunculkan kontradiksi antara aturan dan realitas. Negara menurut menurut Tan Malaka adalah sebuah negara yang berjalan secara efektif dan efisien. 
Artinya demokrasi parlemen bukanlah satu-satunya bentuk demokrasi perwakilan atau bukan satu-satunya cara pengaturan negara.

Pembagian kekuasaan yang terdiri atas eksekutif, legislatif dan yudikatif (parlemen) hanya menghasilkan kerusakan. Pelaksana dilapangan (eksekutif) adalah pihak yang langsung berhadapan dengan persoalan yang sesungguhnya. Eksekutif selalu dibuat repot menjalankan tugas ketika aturan dibuat orang orang yang hanya melihat persoalan dari jauh (parlemen). Demokrasi dalam parlemen biasanya melakukan ritual sekali dalam 4, 5 dan 6 tahun. Dalam kurun waktu demikian lama, mereka sudah menjelma menjadi kelompok sendiri yang sudah berpisah dari masyarakat. mereka telah memiliki kelas yang jauh di atas masyarakat. sedangkan kebutuhan dan pikiran rakyat berubah-ubah. Karena para anggota parlemen itu tak tercampur-baur lagi dengan rakyat, seharusnya mereka tak berhak lagi disebut sebagai wakil rakyat.

Tan Malaka mengatakan keberadaan Parlemen dalam Republik tidak perlu ada, artinya sebuah negara Indonesia kelak tidak memerlukan parlemen. Karena pendirian ini pula Tan Malaka sangat keras menentang maklumat wakil presiden Nomor X pada 1945 tentang pendirian partai-partai. Sebab partai-partai pasti bermuara di parlemen dan akhirnya menjadi suatu kesatuan dengan pemerintah (eksekutif), negara dalam mimpi Tan Malaka dikelola oleh sebuah organisasi tunggal. Dalam tubuh organisasi itulah dibagi kewenangan sebagai pelaksana, sebagai pemeriksa atau pengawas dan sebagai badan peradilan.

\section{E. Menuju Republik Indonesia}

Republik dalam pandangan Tan Malaka itu adalah segala putusan berada ditangan rakyat, bahkan apabila itu putusan terakhir. Suara rakyat itu juga menunjukkan jauhnya kemerdekaan rakyat dalam suatu negara. Menyoal bentuk suatu negara merdeka, Tan Malaka juga mengatakan bahwa dalam artian Republik ada juga jenisnya. Karena tidak semua yang berbentuk Republik itu besar golongan tidak memiliki semua hak. Maka dalam hal ini jenis-jenis negara berbentuk Republik juga 
ada yakni, Republik Aristokratis (kaum ningrat yang berkuasa) seperti Republik Sparta di masa lampau, Republik Plutokratis (hartawan yang berkuasa) dan ada pula Republik Demokratis, disinilah rakyat yang berkuasa.

Didalam Negara berbentuk Republik Demokratis adalah rakyat yang berkuasa dalam semua. Inilah sebenarnya watak negara modern yang besar di zaman sekarang. Disinilah rakyat yang berdaulat menentukan mana yang baik atau tidaknya undangundang yang memilih dan melepas presiden, para menteri dan wakil dewan negara. Dan dalam pandangan Tan Malaka disinilah hak lahir dan batin hampir seluruh lapisan masyarakat terjamin.

Republik dalam gagasan Tan Malaka tidak seturut dengan Trias Politika ala Montesquieu, Republik versi Tan Malaka adalah sebuah negara yang dikelola oleh sebuah organisasi tunggal seperti yang sudah penulis jelaskan diatas. Jelas bahwa Tan Malaka tidak percaya Parlemen, menurutnya pembagian kekuasaan yang terdiri dari eksekutif, legislatif dan yudikatif hanya mendatangkan kerusakan negara. Pemisahan antara orang-orang yang membuat undang-undang dan yang menjalankan aturan menimbulkan kesenjangan antara aturan dan realitas.

\section{a. Upaya Tan Malaka dalam Mewujudkan Konsep Negara Menurut Idealnya}

Pada esensinya pemikiran-pemikiran dan perjuangan Tan Malaka terpusat kepada tujuan bagaimana memerdekakan bangsanya sekaligus merombak secara total seluruh tatanan ekonomi, politik, sosial dan budaya. Jauh sebelum Sukarno menulis Indonesia Menggugat pada tahun 1932 yang berisi arti penting kemerdekaan bagi bangsa Indonesia atau Hatta dengan Kearah Indonesia Merdeka pada tahun 1930, sementara Tan Malaka suda menulis pamplet berjudul Naar De Republik Indonesia (Menuju Republik Indonesia) sebagai konsepsi menuju kemerdekaan Indonesia yang terbit pertama kali di Kowloon Cina, paril 1925 semasa pengasingannya. Semua tentang ide, program dan konsep negara Indonesia telah ia tuangkan di dalamnya.

Tekadnya untuk bergabung dengan dalam pergerakan kemerdekaan membuatnya masuk kedalam tubuh Partai Komunis Indonesia (PKI) yang notabene 
adalah Partai Komunis pertama di Asia yang didirikan diluar Uni Soviet. Tekadnya yang kuat menjadi komitmen dan totalitasnya dalam gerakan tidak pudar. Setelah di PKI ia merencanakan pengorganisasian dalam bentuk pendidikan bagi anggotaanggota PKI dan SI untuk menyusun sistem kursus-kursus kader serta ajaran komunis, keahlian berbicara, jurnalistik serta keahlian mengorganisasikan rakyat.

Untuk mempermudah perjuangan Tan Malaka terhadap kemerdekaan. Ia pun mulai memikirkan alat politik yang henda ia pakai sebagai alat kendara untuk mencapai tujuannya. Pada tahun 1927 Tan Malaka mendirikan PARI di Bangkok, Thailand. Dan PARI menolak berkoordinasi dengan komintern (Poeze, 1988:356). Bersamaan dengan Soebakat dan Djamaluddin Tamin mengumumkan PARI bahwa partai ini independen dari komintern maupun PKI. Perjuangan PARI berdasarkan Pamflet Naar De Republik Indonesia sebagai gerakan bawah tanah untuk memimpin jalannya Revolusi Indonesia menggantikan peran PKI. Namun PARI sebagai gerakan kiri di Indonesia dan sebagai gerakan revolusi tidak bias berkembang di Indonesia setelah dua tokoh kepercayaan Tan Malaka tertangkap.

Tan Malaka menguraikan gagasan merdeka 100 persennya secara lebih detail dalam brosur yang ia tulis di Surabaya. Brosur tersebut berjudul politik yang kemudian dilanjutkan dengan ditulisnya Rencana Ekonomi dan Moeslihat. Ketiga brosur ini merupakan satu rangkaian yang saling berkaitan. Tan Malaka mengawali penjabaran gagasan merdeka 100 persen melalui perumpaan burung gelatik. Burung gelatik terlihat seperti maklhuk yang lemah dan selalu diintai musuhnya. Didahan yang rendah ia harus waspada kucing dan didahan yang tinggi ia harus waspada terhadap elang. Ia hidup dalam ketakutan dan dengan perasaan terancam. Bagi Tan Malaka Indonesia harus bebas dari teror pemangsa dan ketakutan.

Dalam bukunya dari penjara ke penjara (289-290) mejelaskan Syarat menjadi suatu negara merdeka harus jelas. Ilmu kenegaraan yang resmi mendefenisikan negera merdeka hanya dengan menggunakan tiga syarat saja, yaitu tentang daerah, penduduk dan pemerintah. Tan Malaka merasa perlu diadakan koreksi dan tambahan karena negara modern tidak bisa hidup dengan aman jika hanya mempunyai tiga syarat 
tersebut. sekurang-kurangnya ada tiga syarat lagi yang harus ada, yaitu perindustrian, bahan logam mentah dan letak yang strategis.

\section{III.KESIMPULAN}

Berdasarkan keseluruhan hasil penelitian yang sudah penulis paparkan berdasarkan hasil analisis. Maka penulis menarik kesimpulan bahwa, genesis pemikiran Tan Malaka dipengaruhi oleh banyak hal,seperti pengaruh budaya dan agama, pendidikan barat, dan paham-paham filsafat dan kegerakan lainnya. Marxisme merupakan salah satu paham yang mengakar kuat dalam diri Tan Malaka. Marxisme adalah paham yang mengikuti pemikiran Karl Marx yakni Materialisme, Dialektika dan Historis. Oleh kerana perbedaan kondisi sosial dan geografis antara Indonesia dan Eropa maka Tan Malaka memikirkan nasib bangsanya yang masih terjajah oleh kolonialisme dan terkurung didalam belenggu mistik (budaya magis). Sementara perjuangan di Eropa saat itu merupakan perjuangan para buruh yang bekerja didalam perusahaan industri yang berkembang pesat saat itu di Eropa. Maka Tan Malaka menuangkan konsep pemikirannya didalam bukunya yang berjudul MADILOG tersebut.

Konsep pemikiran Tan Malaka memandang materialisme adalah cara berpikir yang tepat, berdasarkan materi (matter) yang terwujud dalam berbagai bentuk. Artinya berfikir itu harus didahulu matter bukan ide. Kemudian Dialektika yang dimaksud adalah pertentangan, pergerakan yang menuju perkembangan cara berfikir. Sedangkan Logika adalah ilmu berfikir yang perlu pertimbangan. Penguraian tentang cara fikir sebagai pemikiran dalam memahami permasalahan politik masa itu dalam induksi, deduksi dan verifikasi, sebagai pekerjaan dari sumbu logika. Sehingga materialisme adalah metode awal, dialektika adalah kritisisme dari materialis dan penutupnya adalah logika (pertimbangan).

Faktor yang menyebabkan karakter politik Tan Malaka diantaranya adalah budaya minangkabau sebagai pengalaman hidup yang awal. Kemudian membawa garis religiusitas sehingga banyak mempengaruhi cara berpikir Tan Malaka. Dalam buku 
Badruddin juga menjelaskan bahwa Sumatera Barat merupakan salah satu wilayah dimana berbagai ideologi bertemu, maka tidak usah heran jika tokoh-tokoh perjuangan kemerdekaan banyak dari Sumatera Barat.

Dalam bukunya dari penjara ke penjara (289-290) mejelaskan Syarat menjadi suatu negara merdeka harus jelas. Ilmu kenegaraan yang resmi mendefenisikan negera merdeka hanya dengan menggunakan tiga syarat saja, yaitu tentang daerah, penduduk dan pemerintah. Tan Malaka merasa perlu diadakan koreksi dan tambahan karena negara modern tidak bisa hidup dengan aman jika hanya mempunyai tiga syarat tersebut. sekurang-kurangnya ada tiga syarat lagi yang harus ada, yaitu perindustrian, bahan logam mentah dan letak yang strategis. 


\section{DAFTAR REFERENSI}

Badruddin. 2014. Kisah Tan Malaka dari Balik Penjara dan Pengasingan.Yogyakarta: Araska

Daliman, A. 2012. Metodologi Penelitian Sejarah. Yogyakarta: Ombak

Djaya, Ashad Kusuma. 2015. Tan Malaka dan Tuhan: Menuju Gagasan PostMADILOG. Yogyakarta: Kreasi Wacana.

Huda, Nimatul. 2010. Ilmu Negara. Jakarta: PT Raja Grafindo Persada

Kuntowijoyo. 2003. Metodologi Sejarah. Yogyakarta: PT Tiara Wacana.

Mona, Matu. 2001. Pacar Merah Indonesia. Penerbit: Perwakilan KITLV dan Penerbit Jendela.

Mrazek, Rudolf. 1994. Semesta Tan Malaka, (Terj.), Endi Haryono dan Bhanu Setyanto. Penerbit: BIGRAF Publishing.

Nasir, Zulhasril. 2007. Tan Malaka dan Gerakan Kiri Minangkabau. Yogyakarta: Penerbit Ombak

Poeze, Harry A. 2008. Tan Malaka, Gerakan Kiri dan Revolusi Indonesia: Agustus 1946 - Maret 1946 Jilid I, (Terj.), Hesri Setiawan, Jakarta: Yayasan Obor Indonesia dan KITLV-Jakarta.

Prabowo, Harry. 2002. Perspektif Marxisme Tan Malaka: Teori dan Praksis Menuju Republik. Yogyakarta: Penerbit Jendela.

Reid, Anthony J. S. 1996. Revolusi Nasional Indonesia. Jakarta: Pustaka Sinar Harapan.

Suhartono. 1994. Sejarah Pergerakan Nasional dari Budi Utomo sampai Proklamasi 1908-1945. Yogyakarta: Pustaka Pelajar.

Sulasman, H. 2014. Metodologi Penelitian Sejarah.Bandung: Pustaka Setia.

Syafiie, Inu Kencana. 2010. Ilmu Politik. Jakarta: Rineka Cipta.

Tan Malaka (1921). 1987. Parlemen atau Soviet. Jakarta: Pimpinan Yayasan Massa (1925). 1987. Naar De 'Republiek Indonesia' (Menuju Republik Indonesia). Yayasan Massa (1926). 2000. Aksi Massa. Jakarta : Teplok Press. (1926). Semangat Muda. Sumber: Indomarxist.net, Tokyo.

(1945). Rencana Ekonomi Berjuang. Sumber: Indomarxist.net, Surabaya.

(1945). Merdeka 100\%: Tiga Percakapan Ekonomi Politik. Marjin Kiri. (1945). Manifesto Jakarta. Sumber: Indomarist.net. (1948). Pandangan Hidup. (1948). 1966. Dari Ir. Soekarno sampai ke Presiden Soekarno. Sumber: Yayasan Cahaya Kita, Jakarta. (2010). Materialisme, Dialektika dan Logika. Yogyakarta: Penerbit Narasi

Utomo, Cahyo. B. 1995. Dinamika Pergerakan Kebangsaan Indonesia dari Kebangkitan Hingga Kemerdekaan. Penerbit: IKIP Semarang Press. 